\title{
PERBANDINGAN FREKUENSI DENYUT JANTUNG BURUNG MERPATI (Columba livia) DENGAN HAMSTER (Tscherskia triton) BERDASARKAN RUANG JANTUNG
}

\author{
Dwi Mutia Sari ${ }^{1}$, Nilawati Putri ${ }^{2}$, Rani Riska ${ }^{3}$, Wulandari ${ }^{4}$, Sri Jayanthi ${ }^{5}$ \\ Prodi Pendidikan Biologi, Fakultas Keguruan dan Ilmu Pendidikan, Universitas Samudra \\ Meurandeh, Langsa Lama, Kota Langsa Aceh, Indonesia \\ Telp.085362180153, Email: dwimutiasari21@gmail.com
}

\begin{abstract}
ABSTRAK
Jantung bekerja melalui beberapa mekanisme secara berulang-ulang dan berlangsung secara terus-menerus. Dengan adanya mekanisme yang secara terus-menerus berulang-ulang maka dapat terlihat denyut jantung tersebut. Tujuan penelitian adalah untuk mengetahui frekuensi denyut jantung pada burung merpati dan hamster. Penelitian ini dilaksanakan pada bulan April 2021 di laboratorium lanjutan Universitas Samudra.Penelitian ini menggunakan penelitian komparatif. Dari hasil penelitian didapatkan hasil bahwa frekuensi denyut jantung hamster lebih tinggi dibandingkan dengan denyut jantung pada burung merpati.
\end{abstract}

Kata Kunci: Jantung, burung merpati, hamster, komperatif.

\section{ABSTRACT}

The heart works through several mechanisms repeatedly and continuously. With a mechanism that is continuously repeated, the heart rate can be seen. The research objective was to determine the heart rate frequency of pigeons and hamsters. This research was conducted in April 2021 in the advanced laboratory of Samudra University. This research used comparative research. The results showed that the hamster's heart rate was higher than that of the pigeons.

Kata Kunci: Heart, pigeons, hamster, comparative.

\section{PENDAHULUAN}

Secara struktur/ anatomi jantung burung merpati( Columba livia) berbeda dengan jantung hamster( Tscherskia triton). Jantung burung merpati terdiri atas 4 ruang dengan sekat sempurna, arteri serta vena. Sistem peredaran darah aves sama dengan peredaran darah manusia. Pada aves darah dari vena kava masuk ke antrium kanan, kemudian ke ventrikel kanan. Setelah itu, darah dipompa keparu- paru. Sebaliknya jantung pada hamster terdiri dari 4 ruangan ialah 2 atrium serta 2 ventrikel yang telah dipisahkan oleh sesuatu septum sehingga jadi ruangan- ruangan yang terpisah secara sempurna( Milton 2013; Hadikastowo, 2011).

Jantung bekerja lewat sebagian mekanisme secara berulang- ulang serta berlangsung secara terus-menerus. Dengan terdapatnya mekanisme yang secara selalu berulang- ulang hingga bisa nampak denyut jantung tersebut. Lewat mekanisme yang secara berseling- seling, jantung berkontraksi buat mengkosongkan isi jantung serta melaksanakan relaksasi guna pengisian darah. Secara siklus, jantung melaksanakan suatu periode sistol ialah periode dikala berkontraksi serta meluangkan isinya( darah), serta periode diastol ialah periode 
yang melaksanakan relaksasi serta pengisian darah pada jantung.

Tujuan penelitian dilakukan adalah untuk mengetahui perbandingan frekuensi denyut jantung merpati (Columba livia) dengan frekuensi denyut jantung hamster (Tscherskia triton) bersumber pada ruang jantung pada masing- masing spesies.

\section{METODE PENELITIAN}

Penelitian ini dilaksanakan pada 26 April 2021 di Laboratorium lanjutan Universitas Samudra. Penelitian ini menggunakan penelitian komparatif yang membandingkan frekuensi denyut jantung burung merpati (Columba livia) dengan hamster (Tscherskia triton) berdasarkan ruang jantung. Penelitian ini menggunakan sampel 3 ekor burung merpati (Columba livia)dalam keadaan sehat (aktif dan tidak cacat). Kemudian hamster dengan berat badan 20-25 gram, dalam keadaan sehat (aktif dan tidak cacat) sebanyak 3 ekor. Sampel didapatkan dari pasar tradisional Kota Langsa. Alat dan bahan yang digunakan dalam penelitian ini adalah pakan hamster dan burung merpati, aquades, eter, larutan ringer dan kapas. Alat yang digunakan adalah loop (kaca pembesar), stopwatch, timbangan, dan peralatan untuk bedah.
Langkah-langkah penelitian dimulai dari pengumpulan data burung merpati dan hamster yang akan dijadikan sampel. Pertama sampel dibius oleh eter kemudian rongga dada di bedah sehingga terlihat organ ruang jantungnya. Selanjutnya menghitung frekuensi denyut jantung yang berdasarkan ruang jantung dari kedua sampel dihitung permenit. Saat frekuensi denyut jantung dihitung, sampel tetap diberikan larutan ranger. Analisis data yang digunakan adalah uji T. Penelitian ini dilakukan dengan 2 perlakuan dan 3 pengulangan. Menurut Steel dan Torri 1989 menyatakan bahwa, dalam setiap percobaan sangatlah penting menyatakan besarnya ketetapan yang diperlukan. Tidak ada gunanya menggunakan 10 ulangan untuk mendeteksi beda yang dapat dilakukan dengan 3 ulangan.

\section{HASIL DAN PEMBAHASAN}

Berdasarkan hasil penelitian mengenai Perbandingan frekuensi denyut jantung merpati (Columba livia) dengan frekuensi denyut jantung hamster (Tscherskia triton) berdasarkan ruang jantung dengan 2 perlakuan dan 3 pengulangan dapat dilihat pada tabel 1 dan tabel 2 sebagai berikut:

Tabel 1. Denyut jantung burung merpati

\begin{tabular}{|c|c|c|c|}
\hline $\begin{array}{c}\text { Ulangan } \\
1\end{array}$ & Ulangan & Ulangan & Rata-rata \\
\hline $98 /$ menit & 2 & 3 & $91,67 /$ menit \\
\hline
\end{tabular}


Tabel 2. Denyut jantung hamster

\begin{tabular}{|c|c|c|c|}
\hline Ulangan & Ulangan & Ulangan & Rata-rata \\
1 & 2 & 3 & \\
\hline $113 /$ menit & $120 /$ menit & $90 /$ menit & $107,66 /$ \\
& & & Menit \\
\hline
\end{tabular}

Tabel 1 dan tabel 2 menunjukkan rata-rata frekuensi denyut jantung burung merpati (Columba livia) permenit sebesar 91.67/ menit, sedangkan rata-rata frekuensi denyut jantung hamster (Tscherskia triton) permenit sebesar 107,66/menit.

Tabel 3. Berat Badan Burung Merpati dan Hamster

\begin{tabular}{|c|c|c|c|}
\hline \multirow{2}{*}{ Hewan } & \multicolumn{3}{|c|}{ Pengulangan } \\
\cline { 2 - 4 } & 1 & 2 & 3 \\
\hline Burung Merpati & $900 \mathrm{gr}$ & $850 \mathrm{gr}$ & $760 \mathrm{gr}$ \\
\hline Hamster & $20 \mathrm{gr}$ & $25,5 \mathrm{gr}$ & $31,5 \mathrm{gr}$ \\
\hline
\end{tabular}

Dari hasil perhitungan data yang sudah dilakukan diperoleh data berat tubuh serta frekuensi denyut jantung mempunyai ciri yang berbeda sehingga dianalisis dengan statistik yang berbeda pula. Hasil berat tubuh mempunyai data yang homogen. baik pada merpai ataupun hamster $(\mathrm{F}=40,21 \mathrm{P}<0,01)$. Sebaliknya informasi denyut jantung memiliki informasi yang homogen $(\mathrm{F}=9,24$ $\mathrm{P}<0,01)$. Dari hasil riset frekuensi denyut jantung merpati permenit lebih rendah dibanding dengan hamster. Merpati mempunyai rata- rata denyut jantung 91, 67 permenit sebaliknya denyut jantung rata- rata hamster 107, 66 permenit. Hasil uji statitistik dengan uji $t$ ada perbandingan rata- rata
Hasil pengamatan berat badan pada burung merpati (Columba livia) dan hamster (Tscherskia triton): 
hormon (Ganong, 2010). Jantung merpati (Columba livia) mempunyai 4 ruang lengkap yang terdiri atas dua serambi dan dua bilik. Selain serambi dan bilik, pada jantung merpati juga terdapat pundi-pundi udara yang dapat membantu proses pernapasan saat mereka sedang terbang. Sistem peredaran darah pada merpati (Columba livia) memiliki sistem peredaran darah tertutup artinya darahnya selalu di dalam pembuluh darah. Sistem peredaran darah

\section{KESIMPULAN}

Dari hasil penelitian disimpulkan bahwa terdapat perbedaan yang signifikan antara frekuensi denyut jantung merpati (Columba livia) dengan frekuensi denyut jantung hamster (Tscherskia triton) berdasarkan dengan ruang jantung keduanya. Berat badan merpati dan hamster tidak mempengaruhi secara signifikan terhadap denyut jantung

\section{DAFTAR PUSTAKA}

Campbell. 2004. Biologi Edisi Kelima Jilid Tiga. Jakarta : Erlangga pada merpati adalah sistem peredarah darah ganda. J

Jantung pada hamster memiliki empat ruang ialah atrium kiri dan atrium kanan serta dua ventrikel kiri dan kanan. Peredaran darah hamster merupakan peredaran darah tertutup dan ganda. Darah yang kaya oksigen dan darah yang kaya karbondioksida telah terpisah dengan sempurna (Dani dan Irfan).

Dani dan Irfan. 2014. Sistem Peredaran Darah Pada Katak. Pustaka Pandani

Ganong, W.F. 2010. Fisiologi Kedokteran. Edisi ke 10. Terjemahan Adhi Dharma.ECG. Penerbit Buku Kedokteran Jakarta.

Milton, H. 2013. Analysis of Vertebrate Structure, Third Edition, United State of America. 